\title{
Partial Characterization of the Intra- and Extracellular Acid Phosphatase of an Alga, Ochromonas danica
}

\author{
By N. J. PATNI AND S. AARONSON \\ Department of Biology, Queens College, City University of New York, \\ Flushing, N.Y. I 1367 , U.S.A.
}

(Received 22 October 1973; revised 8 February 1974)

\begin{abstract}
SUMMAR Y
Intra- and extracellular acid phosphatases were purified 88- and 65-fold respectively from photoheterotrophic Ochromonas danica Pringsheim. The purified enzymes differed in heat inactivation, substrate specificity, and inhibition by several divalent cations and $\mathrm{NaF}$. Intracellular enzyme lost only $30 \%$ of its activity by heating at $60{ }^{\circ} \mathrm{C}$ for $200 \mathrm{~min}$ whereas the extracellular enzyme lost $80 \%$. Both enzymes were active over a broad $\mathrm{pH}$ range from $2 \cdot 2$ to $5 \cdot 2$ and had an optimum $\mathrm{pH}$ of $4 \cdot 8$. Both had broad substrate specificity and differed in their relative ability to hydrolyse $\beta$-glycerophosphate, phenolphthalein diphosphate, glucose-I-phosphate, fructose-I,6-diphosphate, ADP and ATP. Both were inhibited by $\mathrm{Co}^{2+}$, $\mathrm{Zn}^{2+}, \mathrm{Hg}^{2+}, \mathrm{Fe}^{3+}$, arsenate, tartrate and fluoroacetate but differed in their inhibition by $\mathrm{Cu}^{2+}, \mathrm{Hg}^{2+}$ and $\mathrm{NaF}$. Intracellular acid phosphatase was more susceptible to inhibition by $\mathrm{Hg}^{2+}$ and $\mathrm{NaF}$, while extracellular acid phosphatase was more susceptible to inhibition by $\mathrm{Cu}^{2+}$. $p$-Chloromercuribenzoate and urea had no effect on either enzyme's activity. EDTA stimulated the activity of both enzymes. The $K m$ for the intra- and the extracellular enzymes was 0.5 and $0.33 \mathrm{~mm}$ respectively with p-nitrophenyl phosphate as the substrate.
\end{abstract}

\section{INTRODUCTION}

Exoenzymes (extracellular enzymes) are commonly found in bacteria (Pollock, 1962; Lampen, 1965) and protozoa (Müller, 1967) but have not been demonstrated critically in algae or phytoflagellates although several claims have been made (see reviews by Fogg, I962; Aaronson, 1973). Recently we described the existence of several exoenzymes in the culture filtrate of the phytoflagellate Ochromonas danica (Aaronson, I97 I; Aaronson, I973). In this paper we present biochemical evidence for the existence of distinct intra- and extracellular acid phosphatases in $O$. danica.

\section{METHODS}

Organism and growth condition. Ochromonas danica L933/2 Pringsheim was maintained in a chemically defined medium (Aaronson \& Baker, 1959) in $5 \mathrm{ml}$ volumes in screw-cap test tubes in a refrigerated incubator at $25^{\circ} \mathrm{C}$ with 125 to $150 \mathrm{ft}$-candle of white fluorescent light. Experimental cultures were grown similarly in $500 \mathrm{ml}$ volumes in $\mathrm{I} 1$, screw-cap Erlenmeyer flasks. Flasks were inoculated with 20000 organisms $/ \mathrm{ml}$ from a 48 to $72 \mathrm{~h}$ culture and incubated for 5 days (exponential-phase organisms).

Harvesting and preparation of extracts. All centrifugation procedures were carried out at $4{ }^{\circ} \mathrm{C}$. Exponential-phase organisms were harvested by centrifugation at $4340 \mathrm{~g}$ for $20 \mathrm{~min}$ in a Sorval RC-2B refrigerated centrifuge. The organisms were resuspended in $40 \mathrm{ml}$ cold distilled water and homogenized with glass beads at $20000 \mathrm{rev} / \mathrm{min}$ for $30 \mathrm{~s}$ in a Sorval 
Omnimixer. The homogenate was kept cold in an ice bath during homogenization. Glass beads and debris were removed by centrifugation at $4340 \mathrm{~g}$ for $20 \mathrm{~min}$ and the supernatant, after appropriate dilutions, was used immediately for the enzyme assay of intracellular acid phosphatase or frozen $\left(-10\right.$ to $\left.-15{ }^{\circ} \mathrm{C}\right)$ and stored for later use. Supernatant obtained after harvesting the exponential-phase organisms was used for the assay of extracellular acid phosphatase secreted into the growth medium.

Enzyme assays and analytical procedures. Acid phosphatase activity was routinely assayed in duplicate by incubating the enzyme for 10 to $15 \mathrm{~min}$ at $37{ }^{\circ} \mathrm{C}$ with p-nitrophenyl phosphate as substrate. The assay mixture ( $1 \cdot 0 \mathrm{ml}$ total volume) contained $0.5 \mathrm{ml} \mathrm{I} 5 \mathrm{~mm}$ - $p$-nitrophenyl phosphate in acetate buffer, $0.3 \mathrm{ml} 0.1$ M-acetate buffer $\mathrm{pH} 3.6,0.2 \mathrm{ml}$ homogenate which contained 20 to $30 \mu \mathrm{g}$ total protein or $0.2 \mathrm{ml}$ supernatant for assay of extracellular acid phosphatase. The reaction was initiated by the addition of substrate and was terminated by the addition of $5 \mathrm{ml} 0 \cdot \mathrm{I} \mathrm{M}-\mathrm{NaOH}$. The $p$-nitrophenol released by the enzyme was measured at $410 \mathrm{~nm}$ in a Hitachi-Perkin Elmer Model 139 spectrophotometer by the method of Bessey, Lowry \& Brock (1946). The rate of reaction was linear with respect to time and enzyme concentration under these conditions.

Enzyme activity towards a number of other phosphate esters was determined by the liberation of inorganic phosphate. Assay mixtures ( $1.0 \mathrm{ml}$ total volume) contained $0.5 \mathrm{ml}$ substrate solution in buffer, $0.3 \mathrm{ml} \mathrm{I} \cdot 0 \mathrm{M}$-acetate buffer $\mathrm{pH} 3 \cdot 6$, and $0.2 \mathrm{ml}$ enzyme solution. After incubation for 10 to $15 \mathrm{~min}$ the reaction was stopped by the addition of $\mathrm{I} \cdot 0 \mathrm{ml} 10 \%$ trichloracetic acid. The liberated inorganic phosphate was determined by the method of Fiske \& SubbaRow (I925) or by the method of Chen, Toribara \& Warner (I956) as modified by Ames \& Dubin (1960). Enzyme units are expressed as $\mu \mathrm{mol} p$-nitrophenol or inorganic phosphate liberated per min; the specific activity was defined as the enzyme units per $\mathrm{ml}$ culture or per mg protein.

Protein was determined by the method of Lowry, Rosebrough, Farr \& Randall (I95I) with crystalline bovine serum albumin (Sigma) as a standard. Buffers were prepared according to the procedures of Gomori (1955). All compounds used were of the highest purity available commercially and were used without further purification.

Purification methods. All preparative procedures were carried out at o to $5{ }^{\circ} \mathrm{C}$ unless otherwise indicated.

Ammonium sulphate fractionation. Solid $\left(\mathrm{NH}_{4}\right)_{2} \mathrm{SO}_{4}(243 \mathrm{mg})$ was added to each $\mathrm{ml}$ of the crude extract. After $\mathrm{I} h$ of stirring, the proteins that precipitated were removed by centrifugation for $20 \mathrm{~min}$ at $25000 \mathrm{~g}$. The supernatant was adjusted to $90 \%$ saturation by the addition of $375 \mathrm{mg}\left(\mathrm{NH}_{4}\right)_{2} \mathrm{SO}_{4}$ to each $\mathrm{ml}$. The protein precipitated by this procedure was dissolved in $0.05 \mathrm{M}$-acetate buffer $\left(\mathrm{pH}_{4} .8\right)$ so that the final protein concentration was $19.5 \mathrm{mg} / \mathrm{ml}$. After dialysis against the same buffer the solution was centrifuged. All the activity was in the supernatant fraction.

In the case of extracellular acid phosphatase, $3 \mathrm{I} 3 \mathrm{mg}$ of solid $\left(\mathrm{NH}_{4}\right)_{2} \mathrm{SO}_{4}$ was added to each $\mathrm{ml}$ of a 5-day-old cell-free culture medium to give $50 \%$ saturation. After I h, precipitated protein was removed by centrifugation and the supernatant was adjusted to $90 \%$ saturation by adding $302 \mathrm{mg}\left(\mathrm{NH}_{4}\right)_{2} \mathrm{SO}_{4}$ to each $\mathrm{ml}$ of supernatant. After $\mathrm{I} \mathrm{h}$ of stirring precipitates were recovered by centrifugation. The pellet was dissolved in $0.05 \mathrm{M}$-acetate buffer $\left(\mathrm{pH}_{4} .8\right)$ to give a final protein concentration of $8.7 \mathrm{mg} / \mathrm{ml}$.

Chromatography on Sephadex G-I00. Sephadex G-100 (30 g) was allowed to swell in water and washed according to the manufacturer's directions. The slurry was washed twice with $110.05 \mathrm{M}$-acetate buffer $\left(\mathrm{pH}_{4} .8\right.$ ) and allowed to equilibrate in the same buffer overnight. The enzyme solution from the previous step $(6 \mathrm{ml})$ was applied to a column 


\section{Table 1. Summary of purification of intracellular acid phosphatase}

\begin{tabular}{|c|c|c|c|c|c|c|c|}
\hline \multicolumn{8}{|c|}{ For experimental details see the text. } \\
\hline $\begin{array}{l}\text { Step } \\
\text { no. }\end{array}$ & Fractions & $\begin{array}{l}\text { Volume } \\
(\mathrm{ml})\end{array}$ & $\begin{array}{l}\text { Activity } \\
\text { (units } / \mathrm{ml} \text { ) }\end{array}$ & $\begin{array}{l}\text { Protein } \\
(\mathrm{mg} / \mathrm{ml})\end{array}$ & $\begin{array}{l}\text { Specific } \\
\text { activity }\end{array}$ & $\begin{array}{c}\text { Recovery } \\
(\%)\end{array}$ & Purification \\
\hline I & Crude extract & 500 & $223 \cdot 7$ & $17 \cdot 0$ & $13 \cdot 16$ & $100 \cdot 0$ & 1 \\
\hline 2 & $\begin{array}{l}40-90 \% \text { saturation } \\
\left(\mathrm{NH}_{4}\right)_{2} \mathrm{SO}_{4}\end{array}$ & $7 \cdot 0$ & III $4 \cdot 0$ & $19 \cdot 5$ & $57 \cdot 13$ & $69 \cdot 7$ & $4 \cdot 34$ \\
\hline 3 & $\begin{array}{l}\text { Pooled fractions from } \\
\text { Sephadex G-100 }\end{array}$ & $48 \cdot 0$ & $101 \cdot 67$ & $0 \cdot 22$ & $462 \cdot 14$ & $43 \cdot 6$ & $35 \cdot 12$ \\
\hline 4 & Second run on Sephadex G-Ioo & & & & & & \\
\hline & I I & $4 \cdot 5$ & 316.9 & 0.368 & $86 \mathrm{I} \cdot \mathrm{I}$ & $12 \cdot 7$ & $65 \cdot 4$ \\
\hline & 12 & $4 \cdot 5$ & $329 \cdot 7$ & 0.282 & $I 169 \cdot I$ & $13 \cdot 2$ & $88 \cdot 8$ \\
\hline & 13 & $4 \cdot 5$ & 234.6 & 0.220 & $1066 \cdot 4$ & $9 \cdot 4$ & $81 \cdot 03$ \\
\hline & 14 & $4 \cdot 5$ & 104.9 & 0.112 & $936 \cdot 6$ & $4 \cdot 2$ & $71 \cdot 17$ \\
\hline
\end{tabular}

$(2.5 \times 82.0 \mathrm{~cm})$ with the acetate buffer at $4{ }^{\circ} \mathrm{C}$ and eluted with the same buffer at a flow rate of about $8 \mathrm{ml} / \mathrm{h}$. Fractions of $4.5 \mathrm{ml}$ were collected and the enzyme was eluted between fractions 20 and 50 . The most active fractions ( 25 to 36 ) were pooled and solid $\left(\mathrm{NH}_{4}\right)_{2} \mathrm{SO}_{4}$ added. The precipitate, with 40 to $90 \%$ saturation, was dissolved in $6 \mathrm{ml}$ buffer and applied to a column $(2 \cdot 5 \times 35 \mathrm{~cm})$ of Sephadex G-100 equilibrated against acetate buffer, $\mathrm{pH} 4 \cdot 8$. The column was eluted at $4{ }^{\circ} \mathrm{C}$ with the same buffer and $4.5 \mathrm{ml}$ fractions were collected. The void volume was about $55 \mathrm{ml}$.

For purification of extracellular acid phosphatase, the enzyme solution from the previous step $(8 \mathrm{ml})$ was applied to a column of Sephadex G-roo. Enzyme was eluted between fractions $2 \mathrm{I}$ and 49 . The most active fractions (4I to 44 ) were pooled. Solid $\left(\mathrm{NH}_{4}\right)_{2} \mathrm{SO}_{4}$ was added to the pooled fractions. The precipitate with 50 to $90 \%$ saturation was dissolved in $6 \mathrm{ml}$ acetate buffer $\left(\mathrm{pH}_{4} \cdot 8\right)$ and applied to a column of Sephadex G-ıoo.

\section{RESULTS}

\section{Purification}

The results of a typical purification of the intracellular acid phosphatase are shown in Table 1 . The highest final purification varied from 65- to 88 -fold purification in different fractions. The specific activity of the purified enzyme varied between 861 and I I 69 units/mg protein. The highest final purification of the extracellular acid phosphatase (Table 2) varied from 44- to 66-fold purification in different fractions. The specific activity of the purified enzyme varied between 970 and 1427 units/mg protein. The elution profile for intra- and extracellular acid phosphatase is shown in Fig. 1.

\section{Properties of the intra- and extracellular acid phosphatase}

Because of the very small quantities of purified enzyme obtained, only the properties of critical importance, i.e. differences in the heat stability, substrate specificity, inhibition and kinetics, were confirmed by using the purified intra- and extracellular acid phosphatase preparations. Therefore, unless otherwise stated, the results expressed here represent the properties of the intra- and extracellular acid phosphatase when using homogenate and culture medium as the enzyme source.

Temperature stability. Both purified and crude intra- and extracellular acid phosphatase were stable for at least two months when stored at -10 to $-15^{\circ} \mathrm{C}$ in $0.05 \mathrm{M}$-acetate buffer, 
Table 2. Summary of purification of extracellular acid phosphatase

For experimental details see the text.

\begin{tabular}{|c|c|c|c|c|c|c|c|}
\hline $\begin{array}{l}\text { Step } \\
\text { no. }\end{array}$ & Fractions & $\begin{array}{l}\text { Volume } \\
(\mathrm{ml})\end{array}$ & $\begin{array}{l}\text { Activity } \\
\text { (units/ml) }\end{array}$ & $\begin{array}{l}\text { Protein } \\
(\mathrm{mg} / \mathrm{ml})\end{array}$ & $\begin{array}{l}\text { Specific } \\
\text { activity }\end{array}$ & $\begin{array}{l}\text { Recovery } \\
(\%)\end{array}$ & Purification \\
\hline I & Supernatant & I 2480 & $3 \cdot 9$ & 0.180 & $21 \cdot 66$ & $100 \cdot 0$ & $\mathbf{I}$ \\
\hline 2 & $\begin{array}{l}50-90 \% \text { saturation } \\
\left(\mathrm{NH}_{4}\right)_{2} \mathrm{SO}_{4}\end{array}$ & 62 & $705 \cdot 4$ & $8 \cdot 75$ & $80 \cdot 62$ & $89 \cdot 8$ & $3 \cdot 72$ \\
\hline 3 & $\begin{array}{l}\text { Pooled fractions from } \\
\text { Sephadex G-100 column }\end{array}$ & 16 & $161 \cdot 9$ & $0 \cdot 348$ & $465 \cdot 23$ & $5 \cdot 3$ & $21 \cdot 48$ \\
\hline 4 & Second run on Sephadex G-I00 & & & & & & \\
\hline & 14 & $4 \cdot 5$ & $24 \cdot 25$ & 0.025 & $970 \cdot 0$ & 0.2 & $44 \cdot 78$ \\
\hline & 15 & $4 \cdot 5$ & $57 \cdot 1$ & 0.04 & $1427 \cdot 5$ & 0.5 & $65 \cdot 9$ \\
\hline & 16 & 4.5 & $41 \cdot 4$ & 0.035 & I I 82.8 & 0.3 & $54 \cdot 6$ \\
\hline & 17 & $4 \cdot 5$ & $27 \cdot 1$ & 0.025 & $1084 \cdot 0$ & $0 \cdot 25$ & 50.05 \\
\hline
\end{tabular}

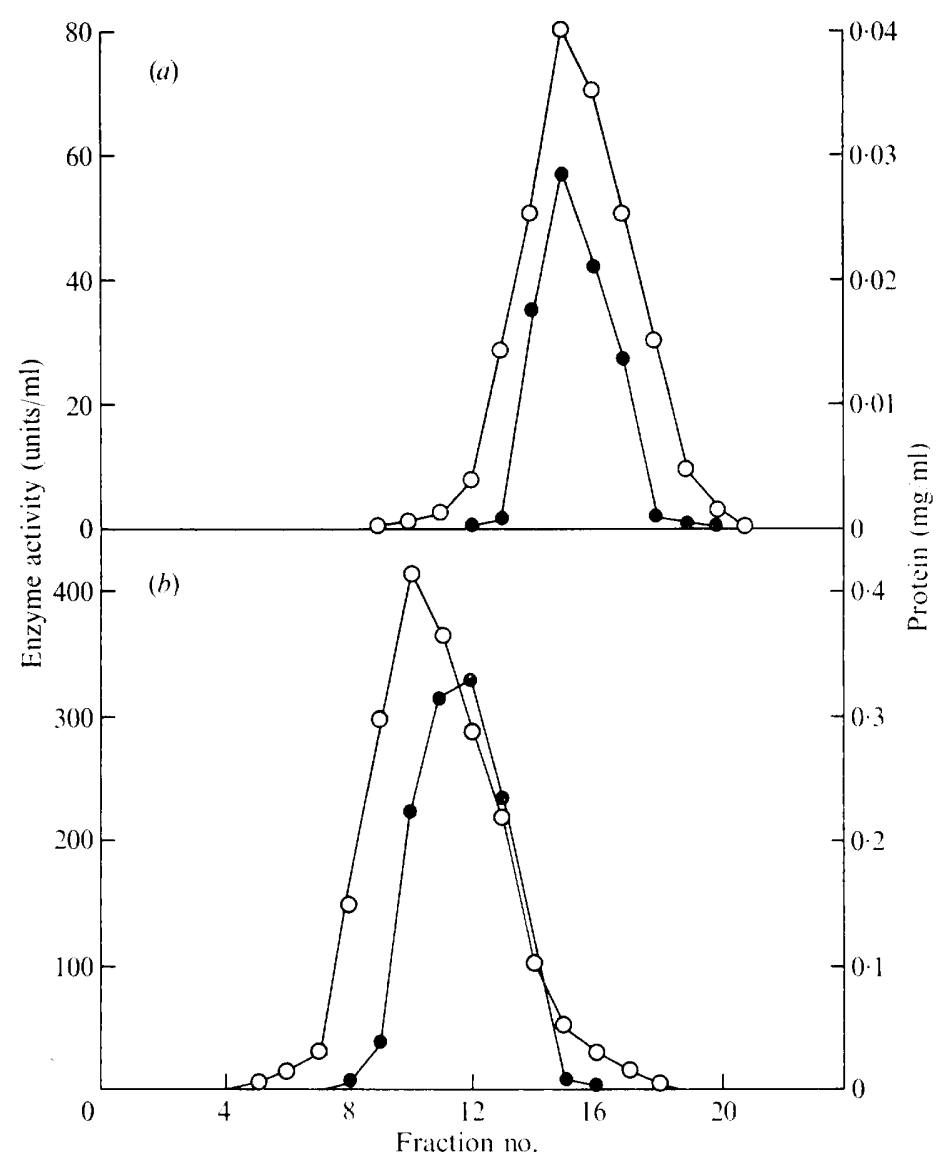

Fig. I. Elution of purified intracellular $(b)$ and extracellular $(a)$ acid phosphatase from Sephadex G-IOo. Details of the procedures used are given in the text. 9 , Enzyme activity; $O$, protein. 


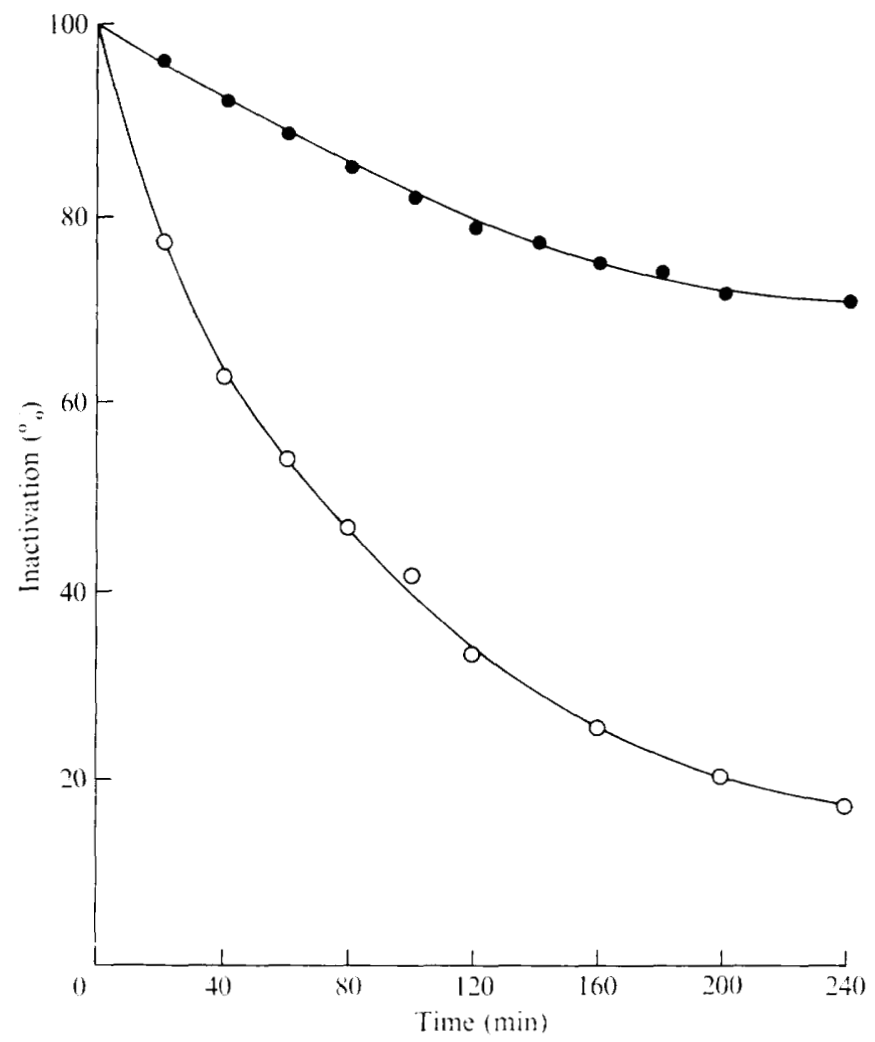

Fig. 2. Thermal denaturation of the phosphatase activity. The enzyme preparations (cell homogenate and cell-free supernatant) containing about $30 \mu \mathrm{g}$ total protein, were heated at $60^{\circ} \mathrm{C}$ in $\mathrm{O} \cdot \mathrm{I} \mathrm{M}$-acetate buffer $\left(\mathrm{pH}_{3} \cdot 6\right)$ for the times indicated. The heating was terminated by transferring a sample into an icebath, and the remaining activity was assayed at $37^{\circ} \mathrm{C}$ as described under the standard assay conditions. - $\mathrm{O}$, Intra- and extracellular acid phosphatase activity, respectively.

$\mathrm{pH} 4.8$. Freezing and thawing had no effect on the enzymic activity. A 15 to $20 \%$ loss in activity of intra- and extracellular enzyme was observed when enzymes were stored at 0 to $5{ }^{\circ} \mathrm{C}$ for two months. The effect of heat treatment of the homogenate and culture supernatant is illustrated in Fig. 2. Heating the enzyme solution for $200 \mathrm{~min}$ at $60^{\circ} \mathrm{C}$ caused about $30 \%$ inactivation of the intracellular acid phosphatase activity; the extracellular enzyme lost about $80 \%$ of its activity. Complete loss of intra- and extracellular acid phosphatase activity was observed when enzyme solution was heated at $80^{\circ} \mathrm{C}$ or above for $20 \mathrm{~min}$. The homogenate was heated for $\mathrm{I} \mathrm{h}$ in a boiling water bath, centrifuged, and the supernatant added to the extracellular enzyme solution before thermal denaturation. No protection of the extracellular enzyme by the heated cell homogenate fraction was observed. Despite their differences in thermal stability, intra- and extracellular acid phosphatases had the same temperature optima. A 2- to $2 \cdot 5$-fold increase in the specific activity of both enzymes was observed at $55^{\circ} \mathrm{C}$ as compared with the specific activity at $37^{\circ} \mathrm{C}$ when using $p$-nitrophenyl phosphate as substrate. Above $60^{\circ} \mathrm{C}$ the activity of intra- and extracellular enzymes declined sharply.

pH optimum. Both intra- and extracellular acid phosphatases had a broad $\mathrm{pH}$ range from $2 \cdot 2$ to 5.2 with an optimum at 4.8 (Fig. 3). At higher $\mathrm{pH}$, phosphatase activity fell very sharply. Only about a $5.0 \%$ difference in activity was observed between $\mathrm{pH} 2 \cdot 2$ and 5.2 , 


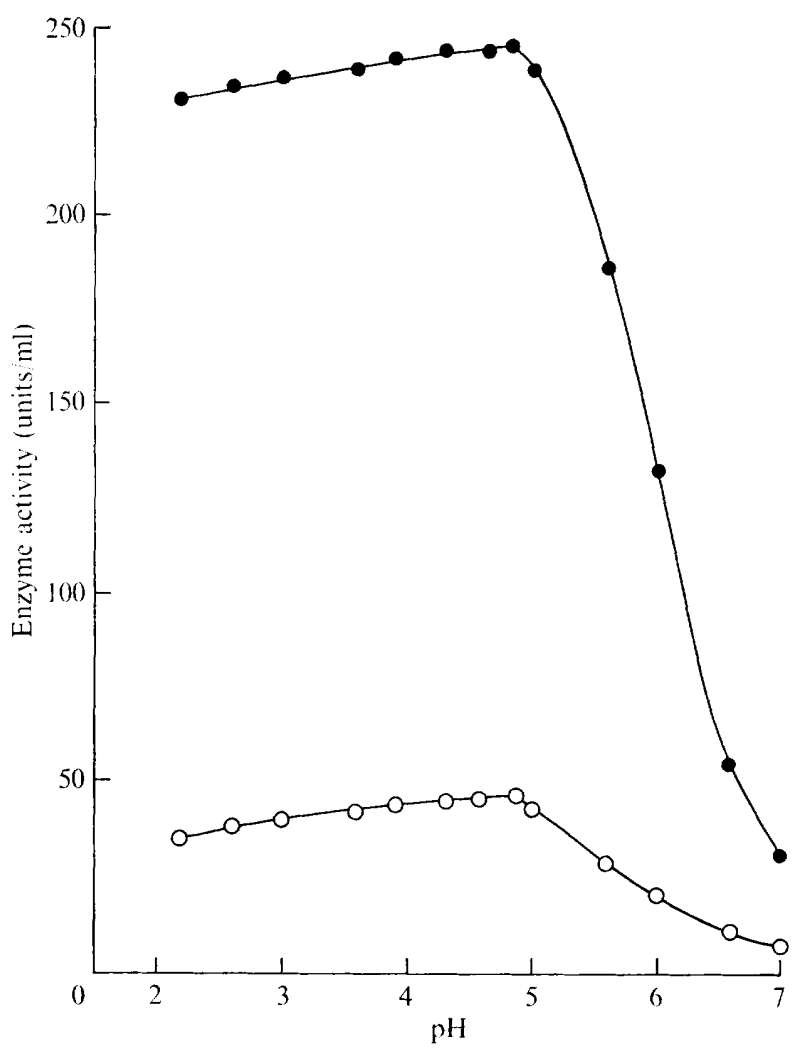

Fig. 3. pH-activity curve for partially purified acid phosphatase. Intracellular (specific activity 1066) and extracellular (specific activity 1084) enzyme preparations were assayed directly at various $\mathrm{pH}$ values in the following buffers at $\mathrm{O} \cdot \mathrm{I} \mathrm{M}$ final concentrations: 2.6 to $3 \cdot 6$, glycine- $\mathrm{HCl} ; 3.6$ to 5.6 , acetate buffer; $5 \cdot 2$ to $7 \cdot 0$, tris-maleate. $\bullet$, $O$, Intra- and extracellular acid phosphatase activity, respectively.

\section{Table 3. Substrate specificity of intra-and extracellular acid phosphatases of Ochromonas danica}

All substrates were assayed at $37^{\circ} \mathrm{C}$ in $0.1 \mathrm{M}$-acetate buffer at $\mathrm{pH} 3.6$. The substrate concentration was $7.5 \mathrm{~mm}$. The specific activities of intra- and extracellular phosphatase with $p$-nitrophenyl phosphate as substrate were 12.0 and $4.9 \mu \mathrm{mol}$ inorganic phosphate liberated $/ \mathrm{min} / \mathrm{ml}$ culture, respectively. The rate of $p$-nitrophenyl phosphate hydrolysis for each enzyme was considered to be $100 \%$ and the other values are indicated as percentages of this value.

\section{Substrate}

$p$-Nitrophenyl phosphate $\beta$-Glycerophosphate Phenolphthalein diphosphate

Glucose 6-phosphate

Glucose I-phosphate

Fructose I,6-diphosphate

Adenosine monophosphate

Adenosine diphosphate

Adenosine triphosphate
Relative rate of hydrolysis

$\begin{array}{rr}\text { Intracellular Extracellular } \\ 100.0 & 100.0 \\ 106.0 & 126.7 \\ 89.0 & 44.8 \\ 97.5 & 94.0 \\ 69.5 & 53.6 \\ 50.5 & 67.7 \\ 114.0 & 114.4 \\ 48.5 & 20.0 \\ 9.1 & 0.0\end{array}$



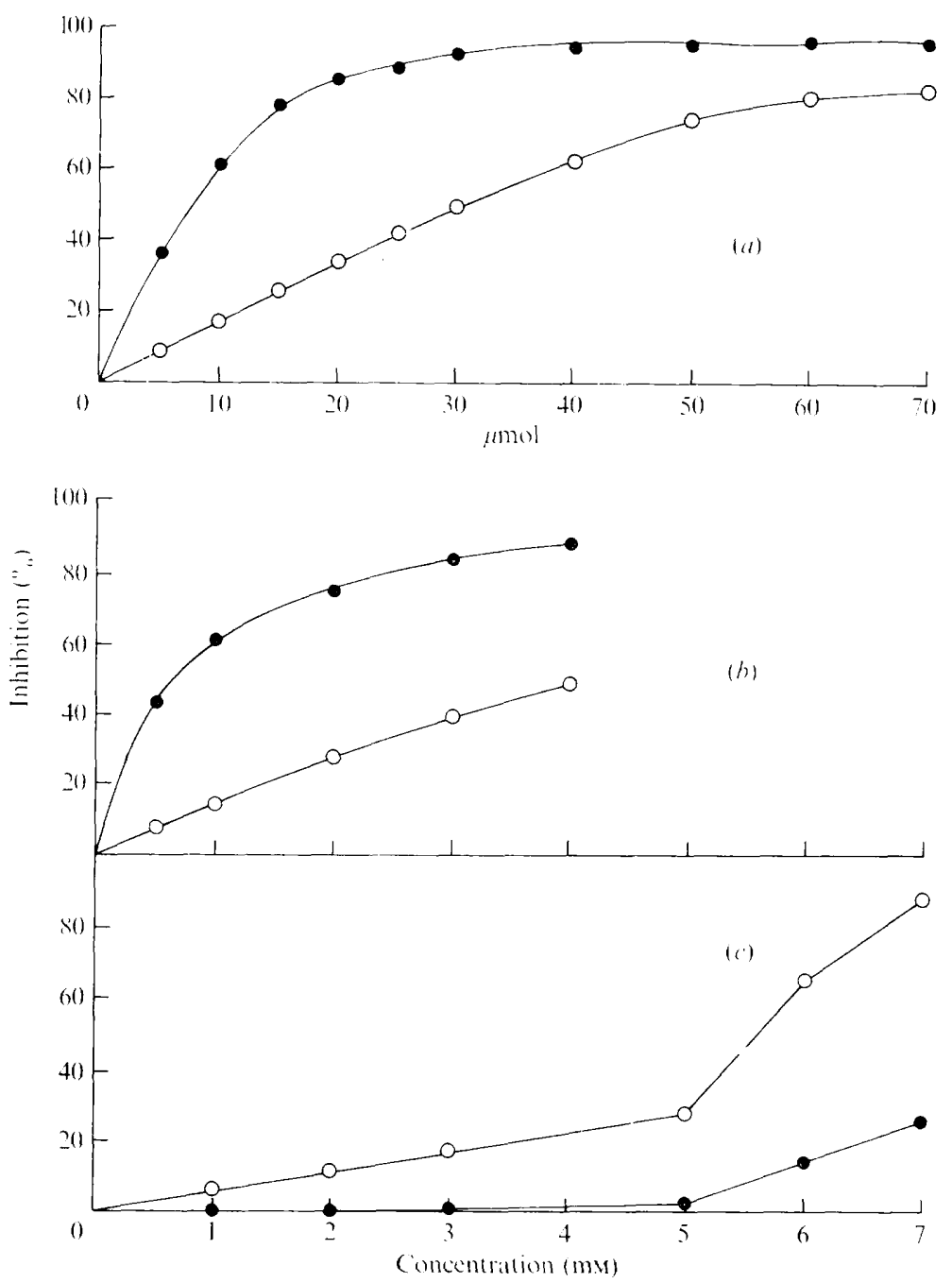

Fig. 4. Effect of $(a) \mathrm{NaF},(b) \mathrm{HgCl}_{2}$, and $(c) \mathrm{CuCl}_{2}$, on the intra- and extracellular acid phosphatase activity. Enzyme was preincubated at $37^{\circ} \mathrm{C}$ for $20 \mathrm{~min}$ with varying concentrations of cations before the addition of $p$-nitrophenyl phosphate as substrate. $\bullet, \bigcirc$, Intra- and extracellular acid phosphatase activity, respectively.

and all subsequent assays were done at $\mathrm{pH} 3 \cdot 6$. Similar broad-range $\mathrm{pH}$ activity was observed with unpurified homogenate and medium.

Substrate specificity. Both enzymes differed in their ability to hydrolyse $\beta$-glycerophosphate, phenolphthalein diphosphate, glucose I-phosphate, fructose I,6-diphosphate, ADP and ATP (Table 3). Both enzymes were unable to hydrolyse DNA or lecithin.

Effect of inhibitors. Cations (at $5 \mathrm{~mm}$ ) were incubated at $37^{\circ} \mathrm{C}$ for $20 \mathrm{~min}$ before addition of $p$-nitrophenyl phosphate as substrate. The presence of $\mathrm{K}, \mathrm{Mg}^{2+}, \mathrm{Ca}^{2+}$ or $\mathrm{Mn}^{2+}$ had no significant effect on either enzyme, whereas $\mathrm{Co}^{2+}, \mathrm{Zn}^{2+}, \mathrm{Hg}^{2+}$ and $\mathrm{Fe}^{3+}$ were equally inhibitory to both enzymes. Extracellular acid phosphatase was more susceptible to inhibition by $\mathrm{Cu}^{2+}$ (Fig. 4c), while $\mathrm{Hg}^{2+}$ was more inhibitory to the intracellular acid phosphatase (Fig. $4 b$ ). 


\section{Table 4. Heat stability of purified intra-and extracellular acid phosphatases}

We used $4.0 \mu \mathrm{g}$ protein/assay system. Purified enzyme in $0 . \mathrm{I}$ M-acetate buffer $\left(\mathrm{pH}_{3} \cdot 6\right)$ was heated for different time intervals at $60^{\circ} \mathrm{C}$. Enzyme activity was assayed at $\mathrm{pH} 3.6$ using $p$-nitrophenyl phosphate as substrate. Results are expressed as relative activity, taking the activity of unheated enzyme as $100 \%$. Variations express differences in the relative activity of purified enzymes as compared with the activity of crude cell homogenate or supernatant.

\begin{tabular}{crr}
$\begin{array}{c}\text { Time of } \\
\text { inactivation } \\
\text { (min) }\end{array}$ & \multicolumn{2}{c}{ Relative activity } \\
\cline { 2 - 3 } 0 & Intracellular & Extracellular \\
40 & I00.0 \pm 0.0 & I00.0 \pm 0.0 \\
I 20 & $90.6 \pm I . I$ & $65.8 \pm 2.9$ \\
240 & $78.35 \pm 0.2$ & $29.0 \pm 3.9$ \\
& $72.15 \pm 0.7$ & $20.25 \pm 3.5$
\end{tabular}

\section{Table 5. Effect of different inhibitors on purified intra- and extracellular acid phosphatases}

We used $4.0 \mu \mathrm{g}$ protein/assay system. Enzyme solution was preincubated with varying concentrations of inhibitors for 20 min at $37^{\circ} \mathrm{C}$ prior to the addition of $p$-nitrophenyl phosphate $(7.5 \mathrm{~mm})$ as substrate. Assay was done using $0 . \mathrm{I} \mathrm{M}$-acetate buffer at $\mathrm{pH} 3.6$. Results are expressed as percentage of relative activity, taking activity with $p$-nitrophenyl phosphate, without addition of an inhibitor, as $100 \%$. Other details are as in Table 4.

\begin{tabular}{|c|c|c|c|}
\hline \multirow[b]{2}{*}{ Additions } & \multirow{2}{*}{$\begin{array}{c}\text { Concentration } \\
(\mathrm{mm})\end{array}$} & \multicolumn{2}{|c|}{ Relative activity } \\
\hline & & Intracellular & Extracellular \\
\hline None & - & $100.0 \pm 0.0$ & $100.0 \pm 0.0$ \\
\hline $\mathrm{CuCl}_{2}$ & $\begin{array}{l}1 \cdot 0 \\
5 \cdot 0 \\
7 \cdot 0\end{array}$ & $\begin{array}{r}100.0 \pm 0.0 \\
97.25 \pm 0.45 \\
90.35 \pm 14.65\end{array}$ & $\begin{array}{c}91 \cdot 25 \pm 2 \cdot 55 \\
67 \cdot 5 \pm 4 \cdot 5 \\
20 \cdot 35 \pm 2 \cdot 85\end{array}$ \\
\hline $\mathrm{HgCl}_{2}$ & $\begin{array}{l}1 \cdot 0 \\
3.0\end{array}$ & $\begin{array}{r}63.5 \pm 17.0 \\
4.5 \pm 7.0\end{array}$ & $\begin{array}{l}81 \cdot 0 \pm 2 \cdot 35 \\
60 \cdot I \pm I \cdot 45\end{array}$ \\
\hline $\mathrm{NaF}$ & $\begin{array}{l}0.01 \\
0.02\end{array}$ & $\begin{array}{l}43.4 \pm 8.6 \\
19.85 \pm 5.25\end{array}$ & $\begin{array}{l}81 \cdot 0 \pm 1 \cdot 7 \\
64 \cdot 8 \pm 2 \cdot 4\end{array}$ \\
\hline
\end{tabular}

Arsenate, tartrate, fluoroacetate, fluoride and iodoacetic acid were found to be potent inhibitors for both enzymes, unlike azide, cystein- $\mathrm{HCl}$, iodoacetamide, $p$-chloromercuribenzoic acid, citrate, urea or EDTA. Fluoride inhibited the intracellular activity more (Fig. 4a). Phosphatase activity was stimulated by chelating agents including EDTA, suggesting that metal ions were not essential for the enzyme activity of both intra- and extracellular acid phosphatase.

Effects of purification. The differences between intra- and extracellular acid phosphatase reported above might be due to an artefact of the crude enzyme preparations. Hence, some of the properties were investigated with the partially purified preparations.

After heating the enzyme at $60{ }^{\circ} \mathrm{C}$ for $240 \mathrm{~min}$, about $30 \%$ of intracellular enzyme activity was lost as compared to almost $80 \%$ inactivation of the extracellular acid phosphatase (Table 4). A purified enzyme preparation was preincubated with different concentrations of $\mathrm{Cu}^{2+}, \mathrm{Hg}^{2+}$ and $\mathrm{NaF}$ for 20 min at $37^{\circ} \mathrm{C}$ before the addition of $p$-nitrophenyl phosphate to study differences in inhibition (Table 5). The minimum and maximum variation observed between the properties of purified and crude enzymes were in the range 0.45 to $8.6 \%$, the only exception being the inhibition with $\mathrm{CuCl}_{2}(7 \mathrm{~mm})$ and $\mathrm{HgCl}_{2}(\mathrm{I} \mathrm{mm})$ when the variation in the activities was 14 to $17 \%$. The intracellular enzyme was appreciably more active with phenolphthalein diphosphate, glucose-I-phosphate or ADP, while the extracellular enzyme was more active with fructose-I,6-diphosphate. The results presented 


\section{Table 6. Effect of mixing the intra- and extracellular enzyme preparations on the differential inhibition of intracellular, extracellular and mixed enzyme preparations}

Two $\mathrm{ml}$ purified intracellular enzyme preparation $(20 \mu \mathrm{g}$ protein $/ \mathrm{ml})$ was mixed with $2 \mathrm{ml}$ of culture supernatant as extracellular enzyme. Four ml each of purified intracellular enzyme, culture supernatant and equally mixed (intra- and extracellular) enzyme preparation were incubated at $25^{\circ} \mathrm{C}$ in a refrigerated incubator with $\mathrm{I} 25$ to $150 \mathrm{ft}$-candle fluorescent light. Enzyme samples were removed at $0,4,8$ and $24 \mathrm{~h}$, preincubated with $5 \mathrm{~mm}-\mathrm{CuCl}_{2}, \mathrm{I} \mathrm{mm}-\mathrm{HgCl}_{2}$, and $10 \mu \mathrm{mol} \mathrm{NaF}$ individually for $20 \mathrm{~min}$ at $37^{\circ} \mathrm{C}$, and assayed for the remaining activity with $p$-nitrophenyl phosphate as substrate. Activity is expressed as absorbance at $410 \mathrm{~nm}$.

I

Time of
incubation

at $25^{\circ} \mathrm{C}$

(h)

o

4
8

24
Intracellular activity (absorbance)
II

Intra- and extracellular activity (absorbance)

$\overbrace{\text { Control } \mathrm{CuCl}_{2}} \overbrace{\mathrm{HgCl}} \mathrm{NaF}$

$\begin{array}{cccc}\text { Control } & \mathrm{CuCl}_{2} & \mathrm{HgCl}_{2} & \mathrm{NaF} \\ 0.300 & 0.250 & 0.195 & 0.170\end{array}$

$0.300-0.255$

$\begin{array}{lll}0.300 & 0.255\end{array}$

$\begin{array}{lll}0.295 & 0.250\end{array}$

$\begin{array}{ll}0.280 & 0.235\end{array}$
0.200

0.190

0.180
0.180

0.170

0.170
III

Extracellular activity (absorbance)

above, and in Tables 3,4 and 5, show that differences between the substrate specificity and inhibition properties of intra- and extracellular acid phosphatases were not due to an artefact of the crude enzyme preparations.

Possibility of conversion of intra- to extracellular enzyme. Purified intracellular acid phosphatase preparation (I) was mixed with an equal volume of crude extracellular enzyme (II), and the mixture incubated at $25^{\circ} \mathrm{C}$ for $24 \mathrm{~h}$ under conditions similar to that for the growth of the culture. As a control, purified intracellular preparation (I) and cell-free supernatant (III) were incubated separately under similar conditions. At different time intervals $(0,4,8$ and $24 \mathrm{~h})$ activity was assayed, without and with inhibitors, with $p$-nitrophenyl phosphate as substrate. Within $24 \mathrm{~h}$ incubation (Table 6), there was no difference in the inhibitory pattern of the various enzyme preparations. Inhibition of the mixed enzyme activity was about half-way between the inhibition of intra- and extracellular acid phosphatases separately. From these results we infer that the differences between the intraand extracellular acid phosphatases are not due to the conversion of one enzyme into the other. Similar results were obtained when purified extracellular enzyme was incubated under the same conditions with an equal quantity of crude intracellular acid phosphatase.

Kinetic studies. When the activities of purified enzymes were measured at various concentrations of $p$-nitrophenyl phosphate as substrate, a double-reciprocal plot (Lineweaver \& Burk, 1934) gave a straight line (Fig. 5). The $K_{m}$ with intra- and extracellular acid phosphatases was 0.5 and $0.33 \mathrm{~mm}$ respectively.

\section{DISCUSSION}

The properties of the intra- and extracellular acid phosphatases of Ochromonas danica described in this paper demonstrate that this alga secretes an enzyme into its environment which is distinctly different from the enzyme inside the cell. Different intra- and extracellular acid phosphatases in another micro-organism, Aspergillus oryzae, have also been reported (Sakurai \& Shiota, 1970).

Unlike the enzyme from the fungus Fusarium moniliforme (Yoshida \& Tamiya, 1971), which was stable up to $40{ }^{\circ} \mathrm{C}$ at $\mathrm{pH} 5 \cdot 3$, the intra- and extracellular acid phosphatases of Ochromonas danica were completely stable at $55^{\circ} \mathrm{C}, \mathrm{pH} 3 \cdot 6$. Both enzymes of $O$. danica differed from the induced acid phosphatase of the phytoflagellate Euglena gracilis (Bennun 


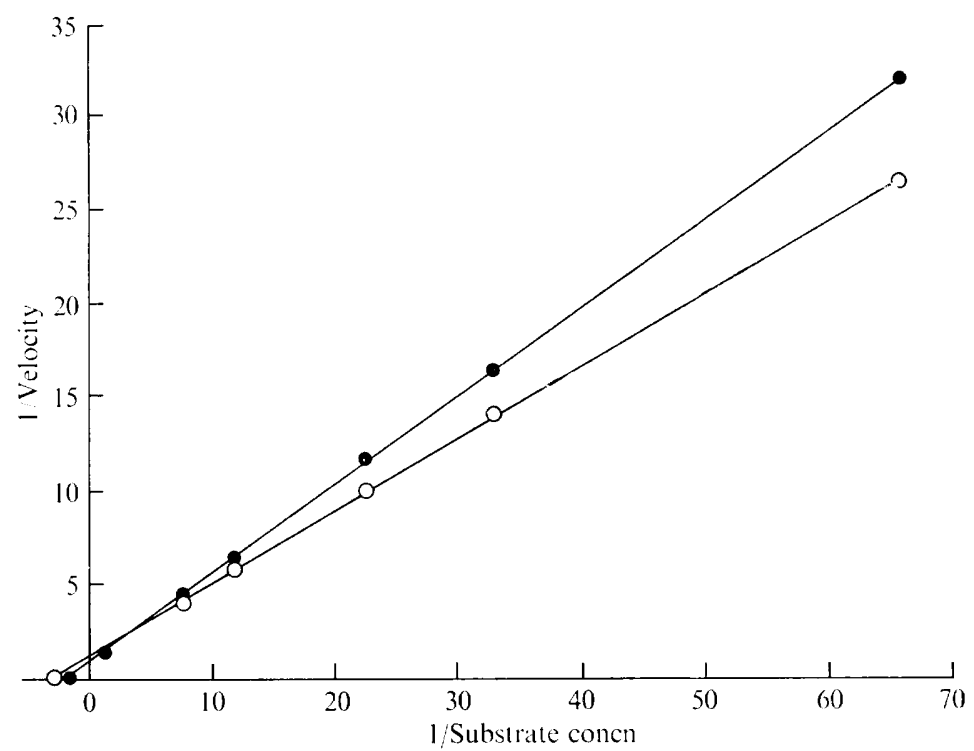

Fig. 5. Rate versus substrate concentration for intra- and extracellular acid phosphatases. The reaction mixture contained in a total volume of $\mathrm{I} \cdot 0 \mathrm{ml}: 3.3$ or $\mathrm{I} \cdot 2 \mu \mathrm{g}$ partially purified intra- and extracellular acid phosphatases, $0.3 \mathrm{ml} \mathrm{O} . \mathrm{I}$ M-acetate buffer $\left(\mathrm{pH}_{3} \cdot 6\right)$, and different concentrations of $p$-nitrophenyl phosphate in buffer as substrate. Incubation was for 10 min at $37{ }^{\circ} \mathrm{C}$. Substrate concentration is expressed in $\mathrm{mm}$ and initial velocity is expressed as mm-p-nitrophenol liberated/ $\mathrm{min} / \mathrm{mg}$ protein. 0 , Intra- and extracellular acid phosphatase, respectively.

\& Blum, I966), which lost almost all activity within $17 \mathrm{~min}$ at $60^{\circ} \mathrm{C}$. Acid phosphatase of the fungus Aspergillus nidulans (Harsanyi \& Dorn, 1972) lost about $50 \%$ activity when heated at $50{ }^{\circ} \mathrm{C}$. The enzymes of $O$. danica were active at a wide $\mathrm{pH}$ range from $2 \cdot 2$ to $5 \cdot 2$ and the optimum $\mathrm{pH}$ for both enzymes was about $4 \cdot 8$. Similar optima for acid phosphatase have been reported for E. gracilis (Blum, 1965), the ciliate Tetrahymena pyriformis (Müller, Baudhuin \& De Duve, I966; Lazarus \& Scherbaum, I967), Acanthamoeba sp. (Müller, 1969), the green alga Chlorella pyrenoidosa (Knutsen, 1968), the fungus $F$. moniliforme (Yoshida \& Tamiya, I97I), and human erythrocyte acid phosphatase (Fenton \& Richardson, 197I) and bone tissue acid phosphatase (Vaes \& Jacques, 1965). An optimum pH of $3 \cdot 2$ has been reported for the acid phosphatase of the amoeba Mayorella palestinensis (Lasman, 1967) while that of Escherichia coli has an optimum pH of 2.5 (Hafkenscheid, I968).

The insensitivity of intra- and extracellular acid phosphatase of Ochromonas danica to metal-binding agents like EDTA implies that these enzymes are not metalloenzymes like the alkaline phosphatase of Escherichia coli (Plocke, Levinthal \& Vallee, 1962). Similar results have been reported for the induced acid phosphatases of Euglena (Bennun \& Blum, I966), Tetrahymena pyriformis (Lazarus \& Scherbaum, 1967), Aspergillus nidulans (Harsanyi \& Dorn, 1972) and hog spleen acid phosphatase (Chersi, Bernardi \& Bernardi, 1966). Like the acid phosphatase of Staphylococcus aureus (Malveaux \& San Clemente, 1969) and bovine-liver acid phosphatase (Heinrikson, 1969), both $O$. danica acid phosphatases were activated by EDTA. Fluoride, tartrate and arsenate inhibit many acid phosphatases (Torriani, I960) as well as the intra- and extracellular acid phosphatases of $O$. danica. Complete inhibition of acid phosphatase by fluoride is also reported in Mayorella palestinensis (Lasman, 1967), the amoeba Chaos chaos (Holter \& Lowy, 1959) and Salmonella 
typhimurium (Carillo-Castaneda \& Ortega, 1967). Blum (1965) observed that fluoride inhibited the induced and constitutive acid phosphatase activity of Euglena. Fluoride at $\mu \mathrm{mol}$ levels inhibited $O$. danica intra- and extracellular acid phosphatases, the intracellular enzyme being more susceptible to inhibition than the extracellular acid phosphatase. Tartrate inhibited the intra- and extracellular acid phosphatases of $O$. danica and the acid phosphatase of Neurospora (Nyc, 1967) and A. nidulans (Harsanyi \& Dorn, 1972) but had no effect on the acid phosphatases of Saccharomyces cerevisiae (Kilsheimer \& Axelrod, 1957, 1958) or S. aureus (Malveaux \& San Clemente, 1969).

The relative specificity of intra- and extracellular acid phosphatases of Ochromonas danica for several substrates indicated little about the natural substrate and role of the enzymes in vivo. The substrate specificity of the intra- and extracellular acid phosphatase was very broad; this is also true of the induced enzyme of Euglena (Bennun \& Blum, I966). However, the enzymes of Euglena gracilis could hydrolyse pyrophosphate much more than p-nitrophenyl phosphate. The acid phosphatase of Fusarium moniliforme (Yoshida \& Tamiya, 1971) and Salmonella typhimurium (Carillo-Castaneda \& Ortega, I967) could also hydrolyse pyrophosphate, ATP and ADP more actively than p-nitrophenyl phosphate. Hydrolysis of pyrophosphate is also reported for the acid phosphatase from tobacco cells (Ueki \& Sato, I97I) and sweet potato (Uehara, Fujimoto \& Taniguchi, I97I). In contrast, both intra- and extracellular acid phosphatases of $O$. danica were unable to hydrolyse pyrophosphate, and ATP was hydrolysed about $10 \%$ with only the intracellular enzyme. Both phosphatases of $O$. danica are more active with the hexose phosphates, AMP and ADP, as substrates than are the acid phosphatase of F. moniliforme (Yoshida \& Tamiya, I97I) and Escherichia coli (Hafkenscheid, r968).

Despite its clear distinction from the intracellular acid phosphatase and similarity to acid phosphatases in other micro-organisms, the role of the extracellular acid phosphatase in Ochromonas danica remains to be determined. To our knowledge this is the first clear demonstration of an extracellular enzyme in an alga (phytoflagellate).

This work was aided by grant GB 20825 from the National Science Foundation.

\section{REFERENCES}

Aaronson, S. (1971). The synthesis of extracellular macromolecules and membranes by population of the phytoflagellate Ochromonas danica. Limnology and Oceanography r6, I-9.

Aaronson, S. (1973). Digestion in phytoflagellates. In Lysosomes in Biology and Pathology, vol. 3, pp. 18-37. Edited by J. T. Dingle. Amsterdam: North-Holland Publishing.

Aaronson, S. \& Baker, H. (1959). A comparative biochemical study of two species of Ochromonas. Journal of Protozoology 6, 282-284.

Ames, B. N. \& Dubin, D. T. (I960). The role of polyamines in the neutralization of bacteriophage deoxyribonucleic acid. Journal of Biological Chemistry 235, 769-775.

Bennun, A. \& Blum, J. J. (I966). Properties of the induced acid phosphatase and of the constitutive acid phosphatase of Euglena. Biochimica et biophysica acta 128, 106-123.

Bessey, O. A., Lowry, O. H. \& Brock, M. J. (1946). A method for the rapid determination of alkaline phosphatase with five cubic millimeters of serum. Journal of Biological Chemistry 164, 32 I-329.

Blum, J. J. (1965). Observations on the acid phosphatases of Euglena gracilis. Journal of Cell Biology $\mathbf{2 4}$, 223-234.

Carillo-Castaneda, G. \& Ortega, M. V. (1967). Effect of inorganic phosphate upon Salmonella typhimurium phophatase activity: non-repressible alkaline phosphatase and non-inhibited acid phosphatase. Biochimica et biophysica acta 146, 535-543.

Chen, P. S., Toribara, T. Y. \& Warner, H. (1956). Microdetermination of phosphorus. Analytical Chemistry 28, I 756-I 758 .

Chersi, A., Bernardi, A. \& Bernardi, G. (1966). Studies on acid hydrolases. II. Isolation and properties of spleen acid phosphomonoesterase. Biochimica et biophysica acta 129, 12-22. 
FENTON, M. R. \& Richardson, K. E. (197I). Human erythrocytic acid phosphatase: resolution and characterization of the isoenzymes from three homozygous phenotypes. Archives of Biochemistry and Biophysics 142, I 3-2I.

Fiske, C. \& SUBbaRow, Y. (I925). The colorimetric determination of phosphorus. Journal of Biological Chemistry 66, 375-400.

FogG, G. E. (1962). Extracellular products. In Physiology and Biochemistry of Algae, pp. 475-489. Edited by R. A. Lewin. New York: Academic Press.

Gomori, G. (1955). Preparation of buffers for use in enzyme studies. In Methods in Enzymology, vol. I, pp. 138-146. Edited by S. P. Colowick and N. O. Kaplan. New York: Academic Press.

HafkensCheid, J. C. M. (I968). Properties of an acid phosphatase in Escherichia coli. Biochimica et biophysica acta $167,582-589$.

HaRSANYI, L. S. \& Dorn, G. L. (1972). Purification and characterization of acid phosphatase from Aspergillus nidulans. Journal of Bacteriology 110, 240-255.

HeinRikson, R. L. (1969). Purification and characterization of a low molecular weight acid phosphatase from bovine liver. Journal of Biological Chemistry 244, 299-307.

Holter, H. \& Lowy, B. A. (1959). A study of the properties and localization of acid phosphatase in the amoeba Chaos chaos L. Comptes rendus des travaux laboratoire Carlsberg 31, $105^{-127}$.

Kilsheimer, G. S. \& Axelrod, B. (I957). Inhibition of prostatic acid phosphatase by $\alpha$-hydroxycarboxylic acids. Journal of Biological Chemistry 227, 879-890.

Kilsheimer, G. S. \& AxeLrod, B. (1958). Phylogenetic distribution of acid phosphatase inhibited by (+) tartrate. Nature, London 182, 1733-1734.

KNUTSEN, G. (1968). Repressed and derepressed synthesis of phosphatases during synchronous growth of Chlorella pyrenoidosa. Biochimica et biophysica acta 16r, 205-214.

LAmpen, J. O. (1965). Secretion of enzymes by micro-organisms. Symposia of the Sociefy for General Microbiology 15, I I5-133.

LASman, M. (1967). Observation on acid phosphatase in Mayorella palestinensis. Journal of Cellular Physio$\log y 69, \mathrm{I} 5 \mathrm{I}-154$.

Lazarus, L. H. \& Scherbaum, O. H. (1967). Some properties of the acid phosphatases of Tetrahymena pyriformis. Life Sciences 6, 240I-2407.

LineweAVER, H. \& BURK, D. (1934). The determination of enzyme dissociation constants. Journal of the American Chemical Society 5o, 658-666.

Lowry, O. H., Rosebrough, N. J., Farr, A. F. \& Randall, R. J. (1951). Protein measurement with the Folin phenol reagent. Journal of Biological Chemistry 193, 265-275.

Malveaux, F. J. \& San Clemente, C. L. (1969). Staphylococcal acid phosphatase: extensive purification and characterization of the loosely bound enzyme. Journal of Bacteriology 97, 1209-1214.

MüLler, M. (1967). Digestion. In Chemical Zoology, vol. I, pp. 351-380. Edited by M. Florkin and B. T. Scheer. New York: Academic Press.

Müller, M. (1969). Lysosomal hydrolases in Acanthamoeba sp. Journal of Protozoology 16, 428-43I.

Müller, M., Baudhuin, P. \& De Duve, C. (1966). Lysosomes in Tetrahymena pyriformis. I. Some properties and lysosomal localization of acid phosphatase. Journal of Cellular Physiology 68, 165-176.

Nyc, J. F. (1967). A repressible acid phosphatase in Neurospora crassa. Biochemical and Biophysical Research Communications 27, I $83-188$.

Plocke, D. J., Levinthal, C. \& Vallee, B. L. (1962). Alkaline phosphatase of Escherichia coli: a zinc metalloenzyme. Biochemistry 1, 373-378.

Pollock, M. R. (1962). Exoenzymes. In The Bacteria, vol. 4, pp. 12I-178. Edited by I. C. Gunsalus and R. Y. Stainier. New York: Academic Press.

SakURai, Y. \& ShIOta, H. (I970). Multiple forms of acid phosphatase produced by Aspergillus oryzae. Journal of General and Applied Microbiology 16, 335-339.

TORRIANI, A. ( 1960$)$. Influence of inorganic phosphate in the formation of phosphatase by Escherichia coli. Biochimica et biophysica acta 38, 460-469.

Uehara, K., Fujimoto, S. \& Taniguchi, T. (1971). Isolation of violet-colored acid phosphatase from sweet potato. Journal of Biochemistry 70, I83-185.

UeKI, K. \& Sato, S. (197I). Effect of inorganic phosphate on the extracellular acid phosphatase activity of tobacco cells cultured in vitro. Physiologia plantarum 24, 506-5 I I.

VAes, G. \& JACQues, P. (1965). Studies on bone enzymes: the assay of acid hydrolases and other enzymes in bone tissue. Biochemical Journal 97, 380-388.

YoshidA, H. \& TAMiYa, N. (I97I). Acid phosphatase from Fusarium moniliforme: purification and enzymatic properties. Journal of Biochemistry 69, 525-534. 